count in honour of Manley's trips to the Broadview area.*

David was a long-time member of Nature Saskatchewan and attended many of the fall and spring meets across Saskatchewan. Like many members, David quietly did his part for the environment. In 1999, David moved to an acreage north of Wolseley where he started to create another birder's paradise. With his wife, Lorrie, he planted over 3000 shrubs and trees and slowly educated his neighbours on the values of wildlife and nature. He conducted annual Christmas Bird Counts in the Broadview area from 1966, and even though he was very ill, he completed a Christmas Bird Count on 26 December 2009.
David said he was born 150 years too late, as he often dreamed of being a pioneer on the prairies and seeing the herds of bison and flocks of passenger pigeons. In his own way, David was a pioneer and had a big influence on people in the Broadview and Wolseley areas with regards to the environment and conservation. Lorrie, his daughter Stephanie, and his granddaughter Anika continue to plant trees on the acreage. David will be missed by his friends and family.

*EDITORS' NOTE: see Don Weidl's article "40th anniversary of the Manley Callin Ekapo Lake Bird Outing", Blue Jay $67: 106-108$, for more on this anniversary bird count.

\title{
IN MEMORIAM: MARY GILLILAND 1940-2010
}

C. STUART HOUSTON, 863 University Drive, Saskatoon, SK, S7N 0J8; E-mail: <stuart.houston@usask.ca>

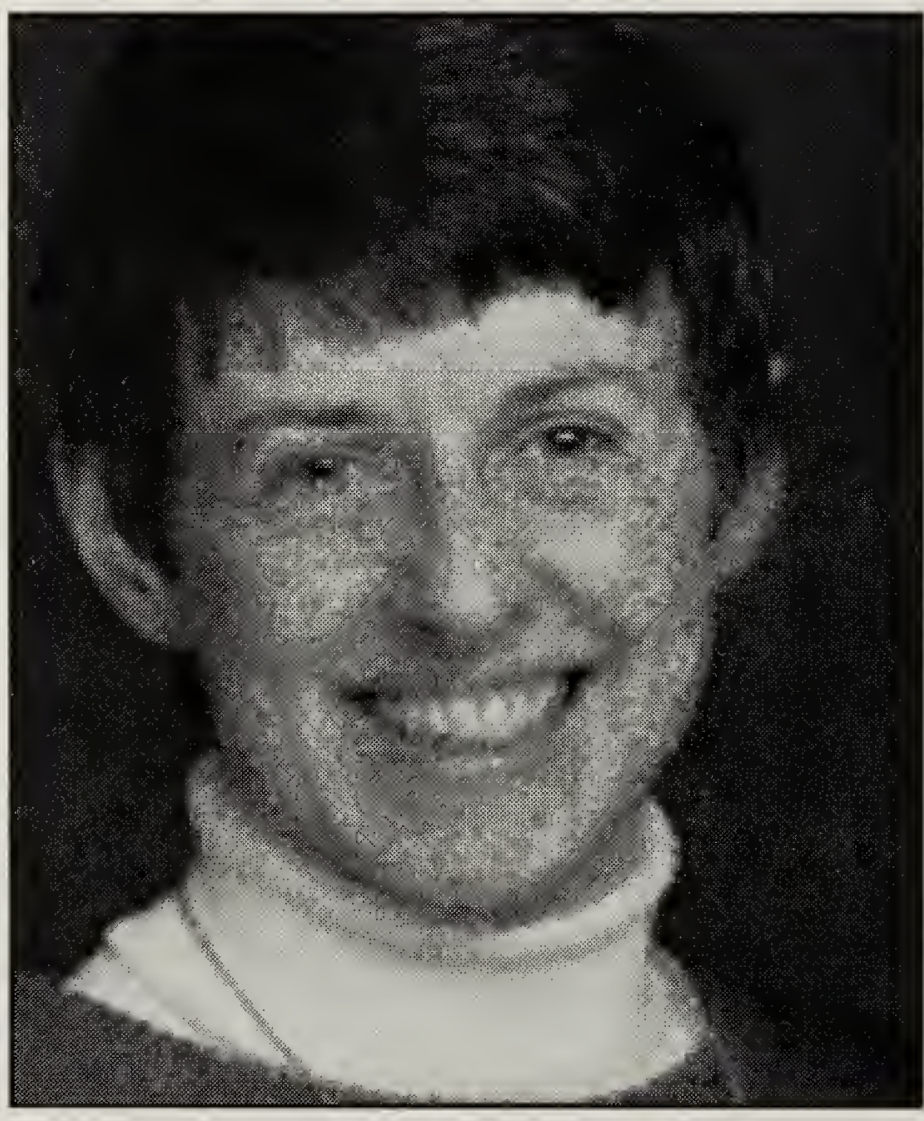

Portrait of Mary Gilliland taken in 1984. Photo courtesy of Sean Gilliland.
On 19 April 2010, Saskatchewan lost a woman originally from Wisconsin who left her mark in numerous ways. Her life was nature-centered, evident even in her e-mail address "birdwoman@....." and her licence plate, "BIRDS-1".

Mary served for 10 years on the board of the Canadian Nature Federation (CNF), the "umbrella group" for provincial and regional nature societies across Canada; for eight of these years she was VicePresident, President, and Past-President - the first Saskatchewan person to be national president. Because of Mary's work that helped achieve proclamation of the Grasslands National Park, the Saskatchewan Society received the Affiliate Award from CNF in 1990. Mary introduced the BirdQuest program to 
Saskatoon. She was a member of a select group of CNF, the Mabel Whittemore Circle.

Mary was always an active member of the Saskatchewan Nature Society. She served as Director of Special Publications from 1982 until 2005, masterminding and editing with punctilious care eight special publications that received national notice during her tenure, including Frank Roy's Birds of the Elbow (1992), Margaret Belcher's The Isabel Priestly Legacy: Saskatchewan Natural History Society 1949-1990 (1996), Al Smith's Atlas of Saskatchewan Birds (also 1996), and Anna Leighton et al.'s Birds of the Saskatoon Area (2002). When the Parks Act was passed in 1986, with a new category of Wilderness Parks, Mary served for 5 years on the Parks Advisory Council to the Department of Parks and Renewable Resources. Mary was Second Vice-President from 1985 to 1986, honoured with Fellowship in 1993, named Volunteer of the Year in 1996, and was Honorary President from 1998 to 2003. She prepared the SNHS brief that successfully opposed a major commercial development on a fragile shore of Redberry Lake where the endangered Piping Plover was nesting.

Locally, from 1982 through 1984, her internal time clock was put out of kilter for all of June, as she did unique studies for Dr. Bernie Gollop to test the validity and consistency of breeding bird counts. She rose at 03:00 $\mathrm{h}$ each morning (!) to begin 5-hour Breeding Bird Surveys near Dundurn shortly after 04:00 h, half an hour before sunrise. She was the instructor for the University Faculty Wives' birding group from 1982 through 2000 (their T-shirts were labelled "Mary's flock"), led numerous bird walks for the Saskatoon and Saskatchewan Societies, and for 20 years led the annual Ante-Grey-Cup (not
anti-Grey Cup!) bird outings in President Murray Park.

For the Saskatoon Nature Society she was Secretary (1981-82), Vice-President (1983), Field Trip Coordinator (1983-84), President (1985-86), Newsletter editor, (1987-88), Field Notes editor (1989), Conservation Director (1990-91), Director (1992), Christmas Bird Count compiler (1987-1994), and occasional Fall Bird Count compiler. She was elected an Honorary (Life) Member in 2007. She both solicited and contributed to Nature Notes in the Saskatoon Sun and in Blue Jay. She wrote a biographical sketch of her heroine, Louise de Kiriline Lawrence, the nurse who cared for the Dionne Quintuplets, and later became a world authority on forest woodpeckers. Mary served on the conservation committee of the Meewasin Valley Authority, inventoried the remaining natural areas near the city, and received their esteemed Conservation Award in 1987.

Mary Hart Deaver was born on 21 March 1940 in Richland Center, Wisconsin. She was valedictorian in her high school class and a member of the National Honor Society in 1958. She won a 4-year scholarship to attend the University of Wisconsin, where she obtained her B.A. Phi Beta Kappa in 1962, majoring in French and Russian, with a year of study in Lublin, Poland. She and fellow student Marshall Gilliland, whom she had married in 1960, then moved to Pullman, Washington, where she taught Russian and French at Washington State University and obtained her M.A. in 1967. Her thesis, concerning a French aviator and author of The Little Prince, was titled "Antoine de Saint-Exupéry: An Essay in Communication." After Marshall obtained his Ph.D. in American History and Literature in 1968, he and Mary moved to Saskatoon, where Marshall 
was a professor of English and headed the humanities and social sciences computing laboratory at the University of Saskatchewan. Marshall took early retirement in 1996 and died of cancer in 2004.

Mary's contributions went far beyond nature and the environment. At the university she taught classes in Russian and French and took a B.Ed. degree, graduating in 1983. For 12 years she served as audiovisual coordinator and then as public information chair for UNICEF Saskatoon. She was one of two longest-serving members of the Saskatchewan Women's Calendar Collective (1982 to 2008), which published the annual Canada-wide Herstory, which featured for each week of each year a full-page biography of an important but usually forgotten woman. She was also a member of the Saskatoon Quilters Guild.

Fighting breast cancer herself for 22 years, she maintained a remarkably optimistic outlook. Mary helped organize the Hope Cancer Centre in the Saskatoon YWCA, walked in the annual Hope Cancer Run, provided individual support to cancer patients, served on the board of the Saskatchewan Cancer Agency for 6 years, and worked with social and survivors' groups involved with Breast Cancer Action Saskatchewan.
In one of the many tributes to Mary, her nominator for honorary membership, Attila Chanady, summed up her contributions to the Saskatoon Nature Society: "Mary Gilliland has made a significant contribution to the study of natural history and to the conservation and educational work of the Saskatoon Nature Society. A birder of considerable expertise, a naturalist of extensive experience, she was a committed member with years of meritorious service; she has inspired and touched the hearts and minds of many who had the good fortune of working with her, or just being in her company on field trips."

Mary is survived by her son Sean Gilliland, daughter-in-law Bernie BoehmGilliland, and granddaughters Alyssa, Taylor, and Emily, all in Saskatoon. A meeting to celebrate her life literally packed Holy Spirit hall on 2 May 2010. Having touched so many in such diverse ways, Mary will be missed.

\section{Acknowledgements}

I thank Cheryl Avery, Attila Chanady, Jodi Joy, Sylvia Chorney, Sean Gilliland, Marina Lawson, Kathy Reid, and Bonnie Piercy for information and Frank Roy for his skilful editing.

Those who contemplate the beauty of the earth find reserves of strength that will endure as long as life lasts. 